\title{
Status Keberlanjutan Wilayah Berbasis Peternakan Sapi Potong Terpadu di Kabupaten Lima Puluh Kota - Sumatera Barat
}

\author{
The Sustainability Status of Integrated Livestock Area in Lima Puluh Kota - West Sumatra \\ Suyitman $^{1}$, S.H. Sutjahjo ${ }^{2}$, dan A. Djulardi ${ }^{1}$ \\ ${ }^{1}$ Fakultas Peternakan Universitas Andalas \\ Kampus Limau Manis Padang, 25163 \\ ${ }^{2}$ Guru Besar Fakultas Pertanian Institut Pertanian Bogor, Darmaga, Bogor \\ e-mail: suyitman_psl@yahoo.co.id \\ (Diterima: 12 Juli 2011; Disetujui: 1 Desember 2011)
}

\begin{abstract}
The aim of this research is to analyze the sustainability status by measuring sustainability index of Kabupaten Lima Puluh Kota area in five dimensions of sustainability. The research methods was Multidimensional Scaling (MDS) that called Rap-BANGKAPET. Rap-BANGKAPET supported with Leverage and Monte Carlo analysis to determine attributes that affects the index and status of sustainability. Sustainability analysis resulted ecological dimension was less sustained (46.50\%), economical dimension was sustained (69.53\%), social and cultural dimension was sustained enough (55.14\%), infrastructure and technology dimension was less sustained (45.48\%), legal and institutional dimension less sustained (47.46\%). From 73 attributes which analysed, only 24 attributes will need to settle immediately because could affects sustainability index sensitively, proven with minimum error at $95 \%$ confidence level. Prospective analysis is needed to build scenarios to increase sustainability index and sustainability status in future. There is progressive-optimistic scenarios with overall improvement at sensitive attributes could increase sustainability status of area.
\end{abstract}

Keywords: Sustainability status ecological, social and cultural, infrastructure and technology, legal and institutional dimension, Kabupaten Lima Puluh Kota Region

\section{PENDAHULUAN}

Untuk mendapatkan manfaat yang optimal, pengembangan pengelolaan peternakan perlu memenuhi kriteria pembangunan berkelanjutan (sustainable development) yang mempersekutukan antara kepentingan ekonomi, sosial budaya, dan kelestarian ekologi (Suyitman dkk., 2009). Diharapkan dengan menerapkan pengembangan kawasan berbasis peternakan sapi potong secara berkelanjutan, dapat meningkatkan pendapatan petani/peternak dan meningkatkan kontribusi terhadap Pendapatan Asli Daerah (PAD), menyerap tenaga kerja dan memeratakan pendapatan, mengaplikasikan teknologi untuk meningkatkan produktivitas, patuh hukum serta berfungsinya kelembagaan peternakan (Suyitman, 2010). Dengan demikian, diperlukan penelitian yang komprehensif untuk merumuskan kebijakan dan skenario pengembangan kawasan berbasis peternakan sapi potong terpadu secara berkelanjutan.
Kabupaten Lima Puluh Kota merupakan salah satu sentra produksi sapi potong di Sumatera Barat yang memiliki potensi pengembangan di masa akan datang. Populasi sapi potong pada tahun 2010 sebanyak 57.236 ekor; mata pencaharian utama masyarakat di bidang pertanian (62\%); yang mendukung dalam penyediaan pakan baik berupa hijauan maupun limbah peranian; terdapat Balai Pembibitan Ternak - Hijauan Makanan Ternak (BPT-HMT) Padang Mengatas sebagai tranformasi teknologi; dan letak wilayah yang strategis karena berbatasan dengan Propinsi Riau sebagai konsumen terbesar produk sapi potong asal Sumatera Barat. Rata-rata pertumbuhan ternak sapi potong di Kabupaten Lima Puluh Kota dalam periode 5 (lima) tahun terakhir (2005-2010) adalah sebesar 9,36\% per tahun. Pemda Sumatera Barat telah menetapkan peternakan sapi potong di Kabupaten Lima Puluh Kota merupakan komoditas 
unggulan dan dikenal sebagai lumbung ternak sapi potong di Sumbar (BPS, 2011).

Di Kabupaten Lima Puluh Kota Sumatera Barat peternakan sapi potong mempunyai potensi yang sangat baik untuk dikembangkan dan telah ditetapkan sebagai komoditas unggulan daerah. Kebijakan ini sangat direspon oleh masyarakat berdasarkan 6 (enam) fakta di lapangan. Pertama, permintaan pasar terhadap komoditas peternakan sapi potong cukup tinggi. Kedua, potensi lahan yang tersedia dan ketersediaan sumber pakan sangat mendukung untuk pengembangan usaha peternakan sapi potong. Ketiga, kesesuaian kondisi agroklimat. Keempat, budaya masyarakat dan tenaga kerja yang terdapat di daerah ini cukup mendukung pengembangan usaha peternakan sapi potong. Kelima, dukungan pemerintah daerah terhadap sektor peternakan sapi potong cukup baik. Keenam, pasar produk peternakan memberikan peluang pasar yang sangat baik. Selain produk peternakan untuk mencukupi kebutuhan masyarakat Kabupaten Lima Puluh Kota, juga untuk melayani permintaan dari kota-kota lain. Hal ini ditunjukkan oleh banyaknya ternak sapi potong yang dipotong serta ternak yang keluar setiap tahunnya (BPS, 2011).

Penelitian ini bertujuan untuk mengetahui status keberlanjutan wilayah berbasis peternakan sapi potong terpadu di Kabupaten Lima Puluh Kota dari lima dimensi keberlanjutan yaitu: dimensi ekologi, dimensi ekonomi, dimensi sosial dan budaya, dimensi infrastruktur dan teknologi, serta dimensi hukum dan kelembagaan. Dengan mengetahui status keberlanjutan wilayah dari lima dimensi, akan memudahkan dalam melakukan perbaikan-perbaikan terhadap atribut-atribut yang sensitif berpengaruh terhadap peningkatan status keberlanjutan wilayah terutama pada dimensi keberlanjutan dengan status yang lebih rendah guna mendukung pengembangan kawasan.

\section{METODE}

\section{Tempat dan Waktu Penelitian}

Penelitian dilaksanakan di Kabupaten Lima Puluh Kota Provinsi Sumatera Barat.
Penetapan lokasi penelitian didasarkan atas pertimbangan Kabupaten Lima Puluh Kota mempunyai potensi yang memungkinkan untuk pengembangan kawasan berbasis peternakan sapi potong terpadu dan didukung dengan sarana dan prasarana umum yang memadai. Penetapan lokasi penelitian dipilih secara sengaja (purposive sampling) sebanyak 3 (tiga) kecamatan, yaitu: Kecamatan Luhak, Situjuah Limo Nagari, dan Lareh Sago Halaban - Kabupaten Lima Puluh Kota Provinsi Sumatera Barat. Penelitian dilaksanakan mulai Bulan Juli sampai Desember 2011. Lokasi penelitian dapat dilihat pada Gambar 1.

\section{Jenis dan Sumber Data}

Jenis data yang diperlukan dalam analisis keberlanjutan pengembangan kawasan berbasis peternakan sapi potong terpadu adalah data primer berupa atribut-atribut yang terkait dengan lima dimensi keberlanjutan pembangunan, yaitu: dimensi ekologi, ekonomi, sosial, teknologi/infrastruktur, serta hukum/kelembagaan. Data primer dapat bersumber dari para responden dan pakar yang terpilih, serta hasil pengamatan langsung di lokasi penelitian.

Teknik penentuan responden dalam rangka menggali informasi dan pengetahuannya ditentukan/dipilih secara sengaja (purposive sampling) dari aspek jumlah ternak yang dimiliki. Pemilihan responden disesuaikan dengan kondisi lingkungan dan jumlah responden yang akan diambil yaitu responden yang dapat dianggap mewakili dan memahami permasalahan yang diteliti. Penentuan responden dilakukan dua cara:

Pertama, responden dari peternak untuk survei sosial ekonomi di lokasi penelitian dilakukan dengan menggunakan metode purposive random sampling. Data sosial ekonomi tersebut digunakan untuk analisis perilaku peternak dan menentukan status serta indeks tingkat perkembangan kawasan berbasis peternakan sapi potong. Jumlah responden (n) dapat ditentukan dengan meng- 
gunakan rumus sebagai berikut: (Kavanagh, 2001).

$$
\mathbf{n}=\frac{\mathrm{N}}{-\cdot-\cdot-\cdot-\cdot-\mathrm{Ne}^{2}}
$$

\section{Keterangan:}

$\mathrm{n}=$ Jumlah responden.

$\mathrm{N}=$ Jumlah populasi (kepala keluarga peternak).

$\mathrm{e}=$ Galat yang dapat diterima $(10 \%)$.

Responden sebanyak 150 (seratus lima puluh) orang diambil dari 3 (lima) kecamatan yang berada di Kabupaten Lima Puluh Kota, yaitu: Kecamatan Luhak, Situjuah Limo Nagari, dan Lareh Sago Halaban - Kabupaten Lima Puluh Kota Provinsi Sumatera Barat. Penentuan responden ditentukan secara acak untuk masing-masing kecamatan. Responden dikelompokkan menjadi 3 (tiga) skala usaha, yaitu: peternak skala usaha kecil (1-3 ekor sapi), peternak skala usaha sedang (4-10 ekor sapi), dan peternak skala usaha besar $(>10$ ekor) sapi.

Kedua, responden dari kalangan pakar. Responden pakar sebanyak 15 (lima belas) orang dipilih secara sengaja (purposive sampling). Responden yang terpilih memiliki kepakaran sesuai dengan bidang yang dikaji. Syarat-syarat responden pakar antara lain: (a) Mempunyai pengalaman yang kompeten sesuai bidang yang dikaji. (b) Memiliki reputasi, kedudukan/jabatan dalam kompetensinya dengan bidang yang dikaji dan telah menunjukkan kredibilitasnya sebagai ahli atau pakar pada bidang yang diteliti. (c) Mempunyai komitmen terhadap permasalahan yang dikaji. (d) Bersifat netral dan bersedia menerima pendapat responden lain. (e) Memiliki kredibilitas yang tinggi dan bersedia dimintai pendapat.

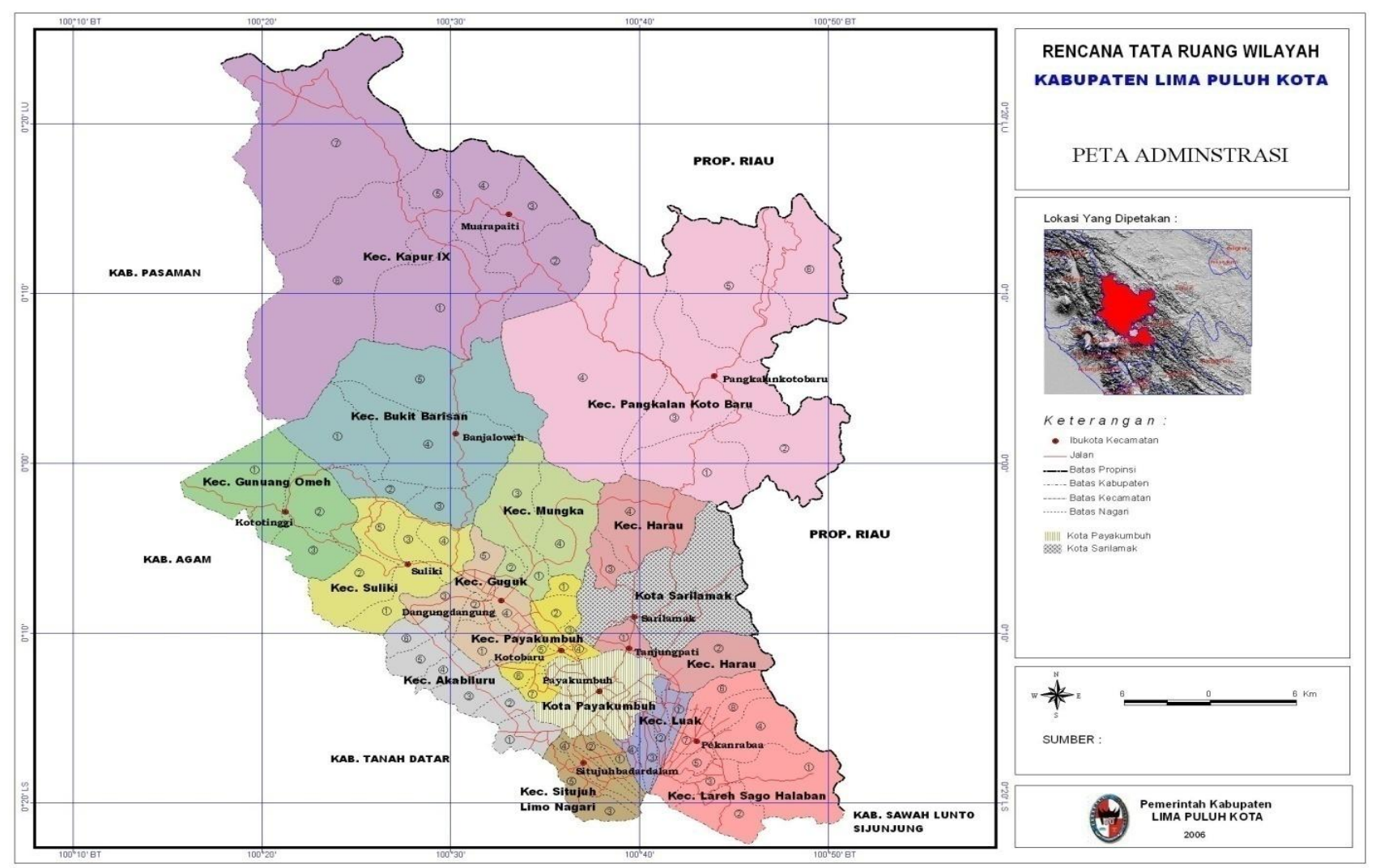

Gambar 1. Lokasi penelitian wilayah berbasis peternakan sapi potong terpadu di Kecamatan Luhak, Situjuah Limo Nagari, dan Lareh Sago Halaban - Kabupaten Lima Puluh Kota Provinsi Sumatera Barat 


\section{Kerangka Analisis}

Analisis tingkat perkembangan kawasan berbasis peternakan sapi potong dilakukan dengan pendekatan Multidimensional Scaling (MDS) yang disebut dengan pendekatan RapBANGKAPET (Rapid Appraisal Pengembangan Kawasan Peternakan) yang merupakan pengembangan dari metode Rapfish yang digunakan untuk menilai status keberlanjutan perikanan tangkap (Kavanagh, 2001). Analisis tingkat perkembangan ini, dinyatakan dalam Indeks Keberlanjutan Pengembangan Kawasan Berbasis Peternakan Sapi Potong.

Analisis dilakukan melalui beberapa tahapan yaitu: (a) penentuan atribut tingkat perkembangan kawasan berbasis peternakan yang mencakup lima dimensi yaitu: ekonomi, ekologi, sosial dan budaya, teknologi/infrastruktur, dan hukum/kelembagaan; (b) penilaian setiap atribut dalam skala ordinal berdasarkan kriteria tingkat perkembangan setiap dimensi; dan (c) penyusunan indeks dan status keberlanjutan kawasan berbasis peternakan sapi potong (Dubrovsky, 2004).

Analisis MDS ditujukan untuk menilai tingkat perkembangan kawasan berdasarkan pada ukuran-ukuran ideal dimensi kawasan yang meliputi: dimensi ekonomi, ekologi, sosial dan budaya, teknologi/infrastruktur, dan hukum/kelembagaan (Barlas, 1996 dan Gao et al., 2003). Adapun atribut (elemen) dari masing-masing dimensi dapat dilihat pada Tabel 1.

Nilai skor dari masing-masing atribut dianalisis secara multidimensional untuk menentukan satu atau beberapa titik yang mencerminkan posisi keberlanjutan pengembangan kawasan yang dikaji relatif terhadap dua titik acuan yaitu titik baik (good) dan titik buruk $(\mathrm{bad})$. Adapun nilai skor yang merupakan nilai indeks keberlanjutan setiap dimensi terdapat pada Tabel 2 .

Melalui metode MDS, maka posisi titik keberlanjutan dapat divisualisasikan melalui sumbu horizontal dan sumbu vertikal. Dengan proses rotasi, maka posisi titik dapat divisualisasikan pada sumbu horizontal dengan nilai indeks keberlanjutan diberi nilai skor $0 \%$ (buruk) dan $100 \%$ (baik). Jika sistem yang dikaji mempunyai nilai indeks keberlanjutan lebih besar atau sama dengan $50 \%$ (> $50 \%$ ), maka sistem dikatakan berkelanjutan (sustainable) dan tidak berkelanjutan jika nilai indeks kurang dari $50 \%(<50 \%)$. Ilustrasi hasil ordinasi nilai indeks keberlanjutan dapat dilihat pada Gambar 2. Nilai indeks keberlanjutan setiap dimensi dapat divisualisasikan dalam bentuk diagram layang-layang (kite diagram) seperti pada Gambar 3.

Tabel 2. Kategori status keberlanjutan pengembangan kawasan berdasarkan nilai indeks hasil analisis Rap-BANGKAPET

\begin{tabular}{cc}
\hline Nilai Indeks & Kategori \\
\hline $0-25$ & Buruk \\
$26-50$ & Kurang \\
$51-74$ & Cukup \\
$75-100$ & Baik \\
\hline
\end{tabular}

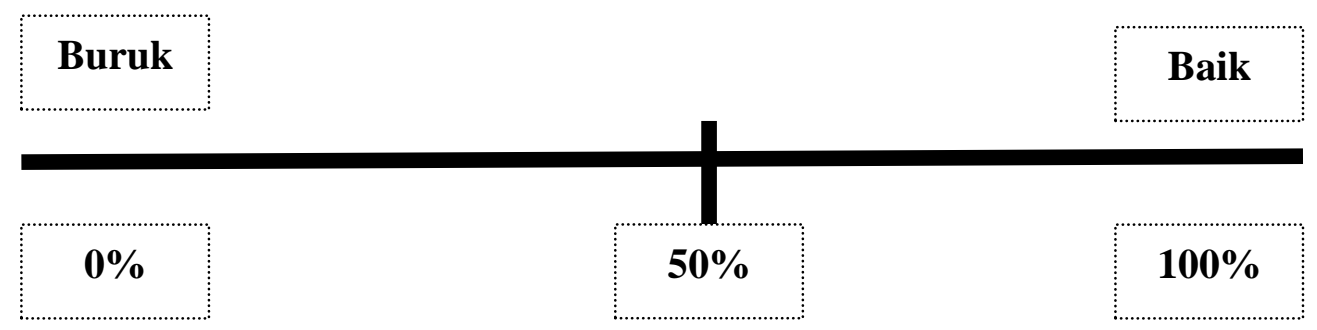

Gambar 2. Ilustrasi indeks keberlanjutan pengembangan kawasan berbasis peternakan sapi potong terpadu sebesar $50 \%$ (berkelanjutan) 


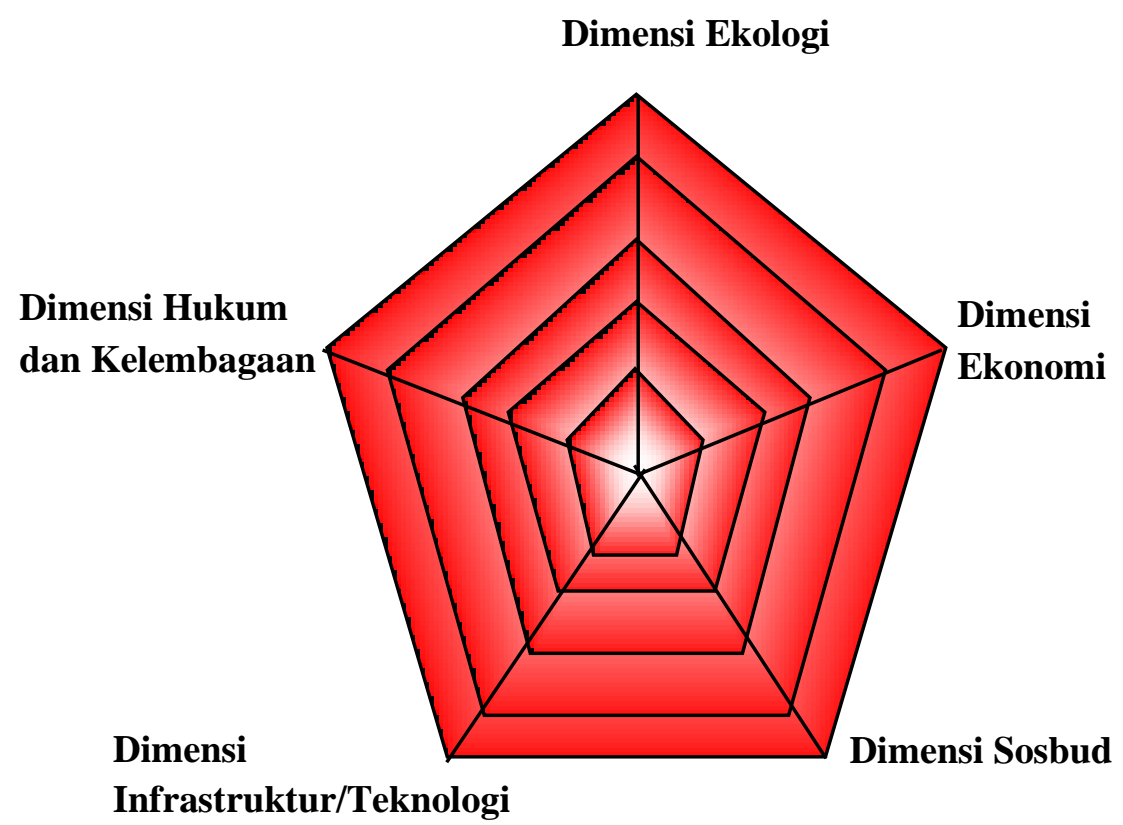

Gambar 3. Ilustrasi indeks keberlanjutan setiap dimensi pengembangan kawasan berbasis peternakan sapi potong terpadu

Untuk melihat atribut yang paling sensitif memberikan kontribusi terhadap indeks keberlanjutan pengembangan kawasan dilakukan analisis sensivitas dengan melihat bentuk perubahan root mean square (RMS) ordinasi pada sumbu X. Semakin besar perubahan nilai RMS, maka semakin sensitif atribut tersebut dalam pengembangan kawasan.

Dalam analisis tersebut di atas akan terdapat pengaruh galat yang dapat disebabkan oleh berbagai hal seperti kesalahan dalam pembuatan skor karena kesalahan pemahaman terhadap atribut atau kondisi lokasi penelitian yang belum sempurna, variasi skor akibat perbedaan opini atau penilaian oleh peneliti, proses analisis MDS yang berulang-ulang, kesalahan pemasukan data atau ada data yang hilang, dan tingginya nilai stress, yaitu nilai stress dapat diterima jika nilai $<25 \%$ (Kavanagh, 2001). Untuk mengevaluasi pengaruh galat pada pendugaan nilai ordinasi pengembangan kawasan digunakan analisis Monte Carlo.

Analisis prospektif dilakukan dalam rangka menghasilkan skenario pengembangan kawasan secara berkelanjutan berbasis peternakan sapi potong terpadu di Kabupaten
Kabupaten Lima Puluh Kota untuk masa yang akan datang dengan menentukan faktor dominan yang berpengaruh terhadap kinerja sistem.

Pengaruh antar faktor diberikan skor oleh pakar dengan menggunakan pedoman penilaian analisis prospektif, yaitu: 0 (tidak ada pengaruh); 1 (berpengaruh kecil); 2 (berpengaruh sedang); dan $\mathbf{3}$ (berpengaruh sangat kuat). Kemungkinan - kemungkinan masa depan yang terbaik dapat ditentukan berdasarkan hasil penentuan elemen kunci masa depan dari beberapa faktor-faktor yang sangat berpengaruh terhadap pengembangan kawasan tersebut (Evans, 2006).

\section{Jenis dan Sumber data}

Jenis data yang diperlukan dalam penelitian ini adalah data primer dan data sekunder. Data primer berupa atribut-atribut yang terkait dengan tingkat perkembangan kawasan berbasis peternakan sapi potong pada lima dimensi yaitu: dimensi ekonomi, ekologi, sosial dan budaya, teknologi/infrastruktur, dan hukum/kelembagaan. Data primer bersumber dari para responden dan pakar yang terpilih, serta hasil pengamatan langsung di lokasi 
penelitian. Data sekunder seperti data produksi peternakan, komoditas unggulan, jumlah penduduk, kegiatan utama masyarakat di sektor peternakan, aksesibilitas kawasan ke kawasan/daerah lainnya, kedekatan dengan pasar, kelengkapan sarana dan prasarana pendukung, potensi lahan untuk mendukung pengembangan kawasan, dan perolehan PDRB, fasilitas pendidikan latihan dan penyuluhan, fasilitas kesehatan hewan dan IB, fasilitas ibadah, fasilitas olah raga, fasilitas keamanan, fasilitas ekonomi seperti ketersediaan pasar dan koperasi unit desa (KUD). Data sekunder ini diperoleh dari instansiinstansi terkait di Kabupaten Lima Puluh Kota, seperti: Bappekab, Dinas Peternakan, Dinas Pertanian, Badan Pusat Statistik (BPS), Kecamatan dan Desa dalam wilayah Kecamatan Luhak, Situjuah Limo Nagari, dan Lareh Sago Halaban - Kabupaten Lima Puluh Kota Provinsi Sumatera Barat.

\section{Metode Pengumpulan Data}

Metode pengumpulan data dalam analisis keberlanjutan pengembangan kawasan berbasis peternakan sapi potong terpadu di Kabupaten Lima Puluh Kota dilakukan melalui wawancara, diskusi, kuisioner, dan survey lapangan dengan responden di wilayah studi yang terdiri atas berbagai pakar dan stakeholder yang terkait dengan topik penelitian ini.

\section{HASIL DAN PEMBAHASAN}

\section{Status Keberlanjutan Wilayah Berbasis Peternakan Sapi Potong Terpadu di Kabupaten Kabupaten Lima Puluh Kota}

Dalam penelitian pengembangan kawasan berbasis peternakan sapi potong terpadu di wilayah Kabupaten Lima Puluh Kota, penentuan indeks keberlanjutan kawasan ditetapkan pada lima dimensi keberlanjutan, yaitu: dimensi ekologi, ekonomi, sosial dan budaya, infrastruktur/ teknologi, serta hukum/kelembagaan dengan atribut dan nilai skoring hasil pendapat pakar. Berdasarkan hasil analisis dengan menggunakan Rap-BANGKAPET (MDS) diperoleh nilai indeks keberlanjutan untuk dimensi ekologi: 46,50 \% (status kurang berkelanjutan), dimensi hukum/kelembagaan: $47,46 \%$ (status kurang berkelanjutan), dimensi infrastruktur/ teknologi: $45,48 \%$ (status kurang berkelanjutan), dimensi sosial budaya: 55,14\% (status cukup berkelanjutan), dan dimensi ekonomi: $69,53 \%$ (status cukup berkelanjutan).

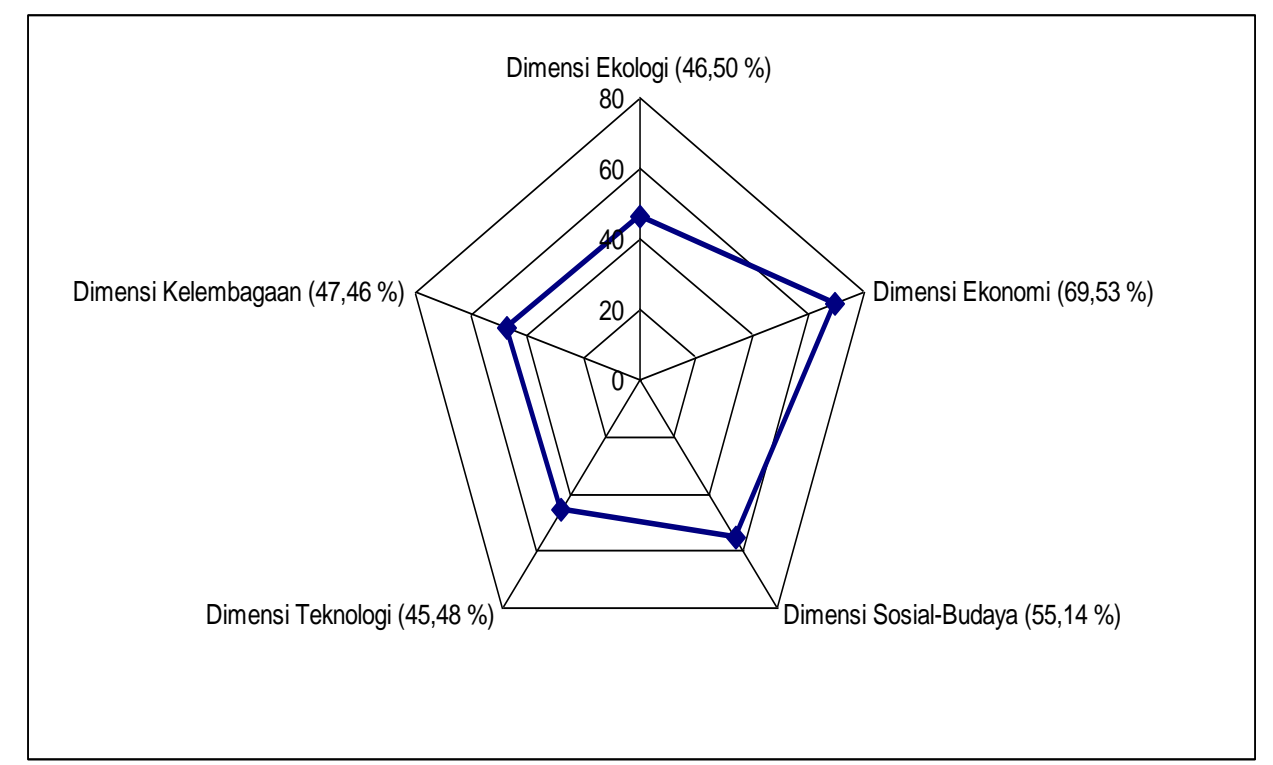

Gambar 4. Diagram layang (kite diagram) nilai indeks keberlanjutan wilayah berbasis peternakan sapi potong terpadu diKabupaten Kabupaten Lima Puluh Kota 
Tabel 3 Faktor-faktor kunci yang berpengaruh dalam pengembangan kawasan berbasis peternakan sapi potong terpadu di Kabupaten Lima Puluh Kota

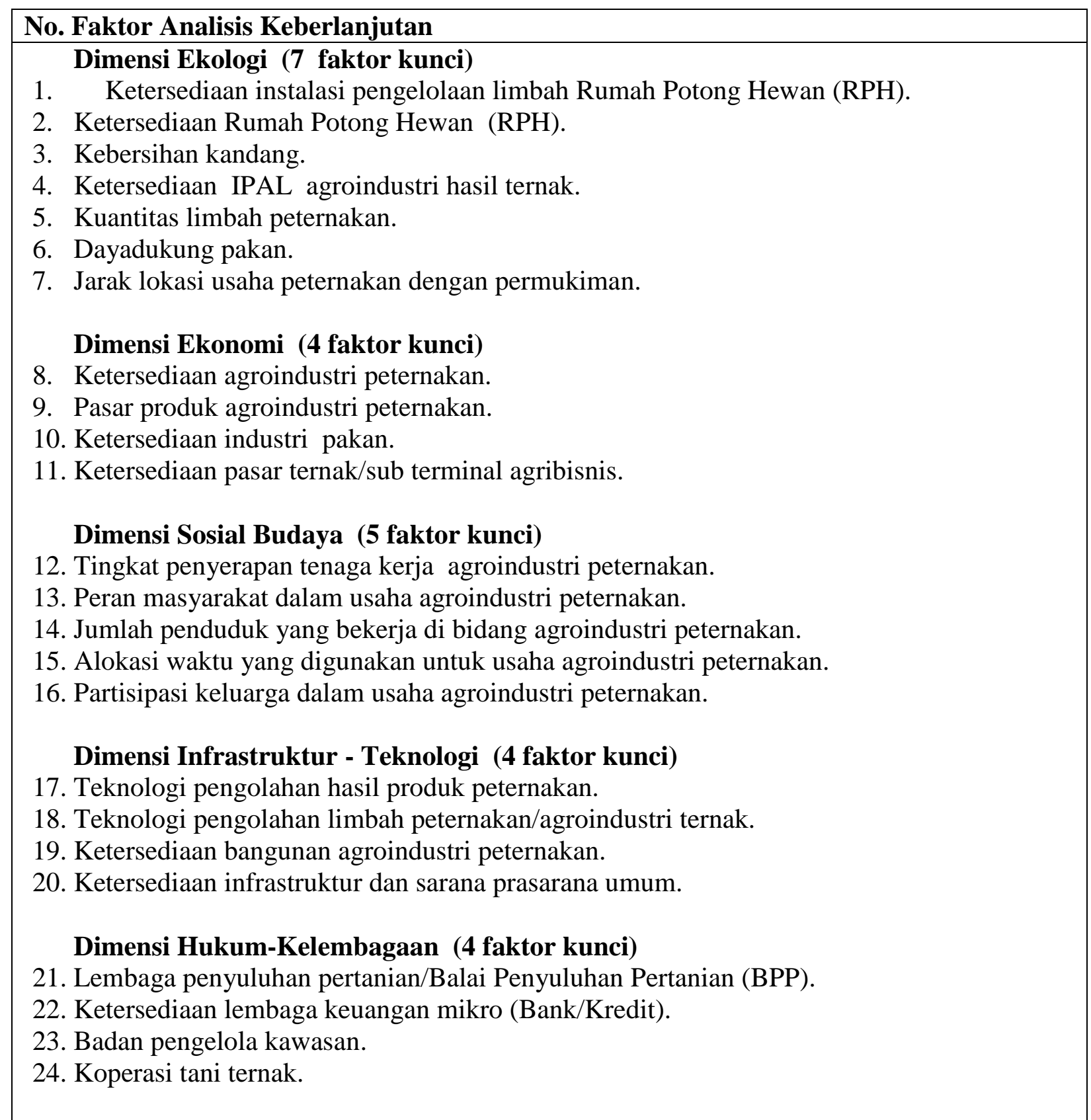

Agar nilai indeks ini di masa yang akan datang dapat terus meningkat sampai mencapai status berkelanjutan, perlu perbaikanperbaikan terhadap atribut yang sensitif berpengaruh terhadap nilai indeks dimensi ekologi, infrastruktur/teknologi, dan hukum/ kelembagaan pada atribut-atribut yang dinilai oleh para pakar didasarkan pada kondisi existing wilayah. Adapun nilai indeks lima dimensi keberlanjutan hasil analisis RapBANGKAPET seperti pada Gambar 4.

\section{Skenario Strategi Pengembangan Wilayah untuk Pengembangan Kawasan Berbasis Peternakan Sapi Potong Terpadu yang Berkelanjutan di Kabupaten Kabupaten Lima Puluh Kota}

Strategi pengembangan wilayah Kabupaten Lima Puluh Kota untuk pengembangan kawasan berkelanjutan berbasis peternakan sapipotong terpadu dilakukan menggunakan analisis prospektif yang bertujuan untuk 
memprediksi kemungkinan yang akan terjadi di masa yang akan datang sesuai dengan tujuan yang ingin dicapai.

Berdasarkan hasil analisis keberlanjutan (MDS) diperoleh 24 (dua puluh empat) faktor atau atribut yang sensitif (Gambar 5, 6, 7, 8, dan 9) dari 73 (tujuh puluh tiga) atribut yang diteliti dan selanjutnya diajukan kepada pakar untuk dianalisis Prospektif (Tabel 3).

Berdasarkan hasil analisis tingkat kepentingan antar faktor diperoleh 7 (tujuh) faktor kunci/penentu yang mempunyai pengaruh kuat dan ketergantungan antar faktor tidak terlalu kuat, yaitu: (1) Ketersediaan agroindustri peternakan, (2) Ketersediaan rumah potong hewan (RPH), (3) Jumlah penduduk yang bekerja di bidang agroindustri peternakan, (4) Koperasi tani ternak, (5) Pasar produk agroindustri peternakan, (6) Ketersediaan bangunan agroindustri peternakan, dan (7) Ketersediaan industri pakan.

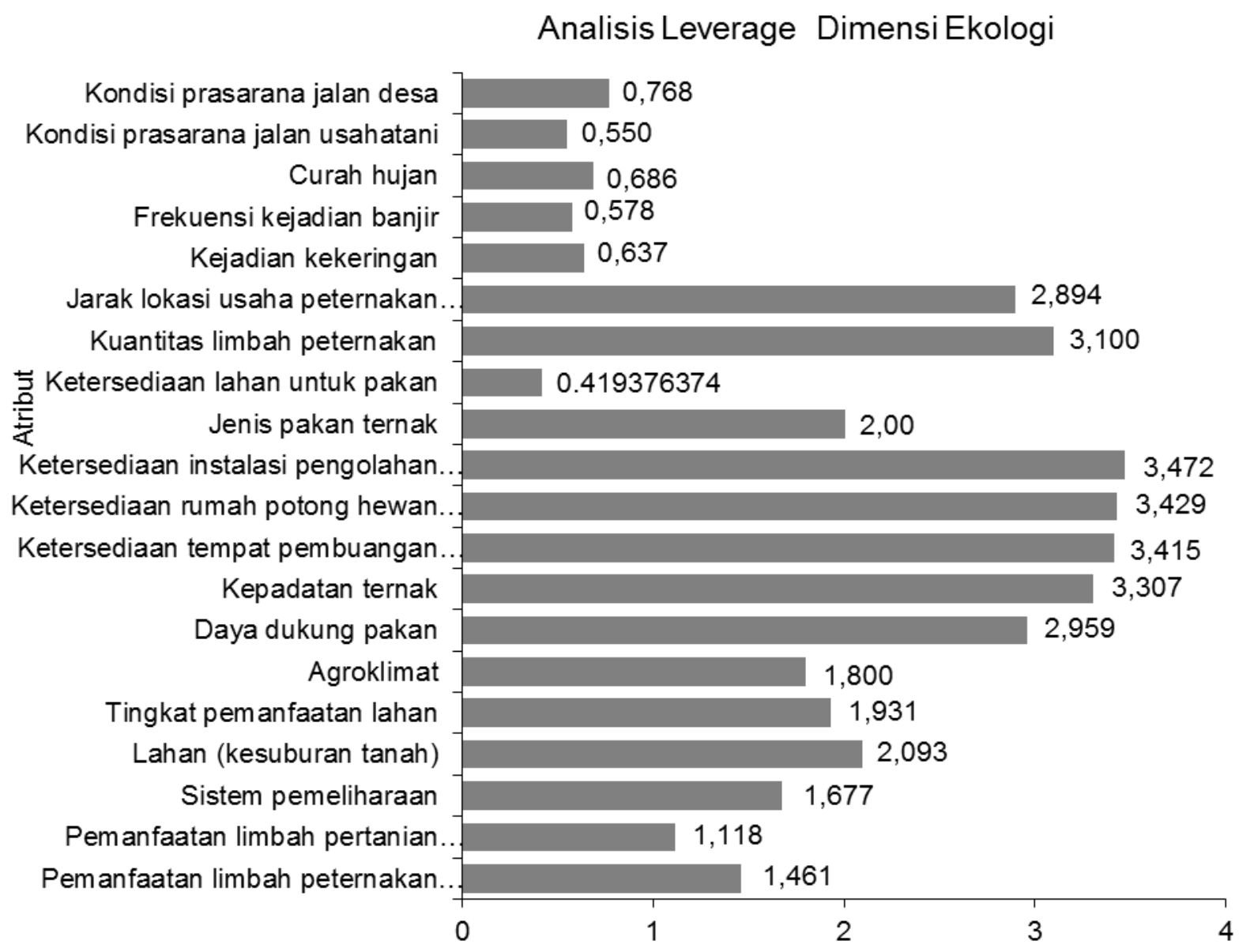

Root Mean Square Change \% in Ordination when Selected Attribute Removed (on Status scale 0 to 100 )

Gambar 5. Peran masing-masing atribut aspek ekologi yang dinyatakan dalam bentuk nilai root mean square (RMS) 


\section{Analisis Leverage Dimensi Ekonomi}

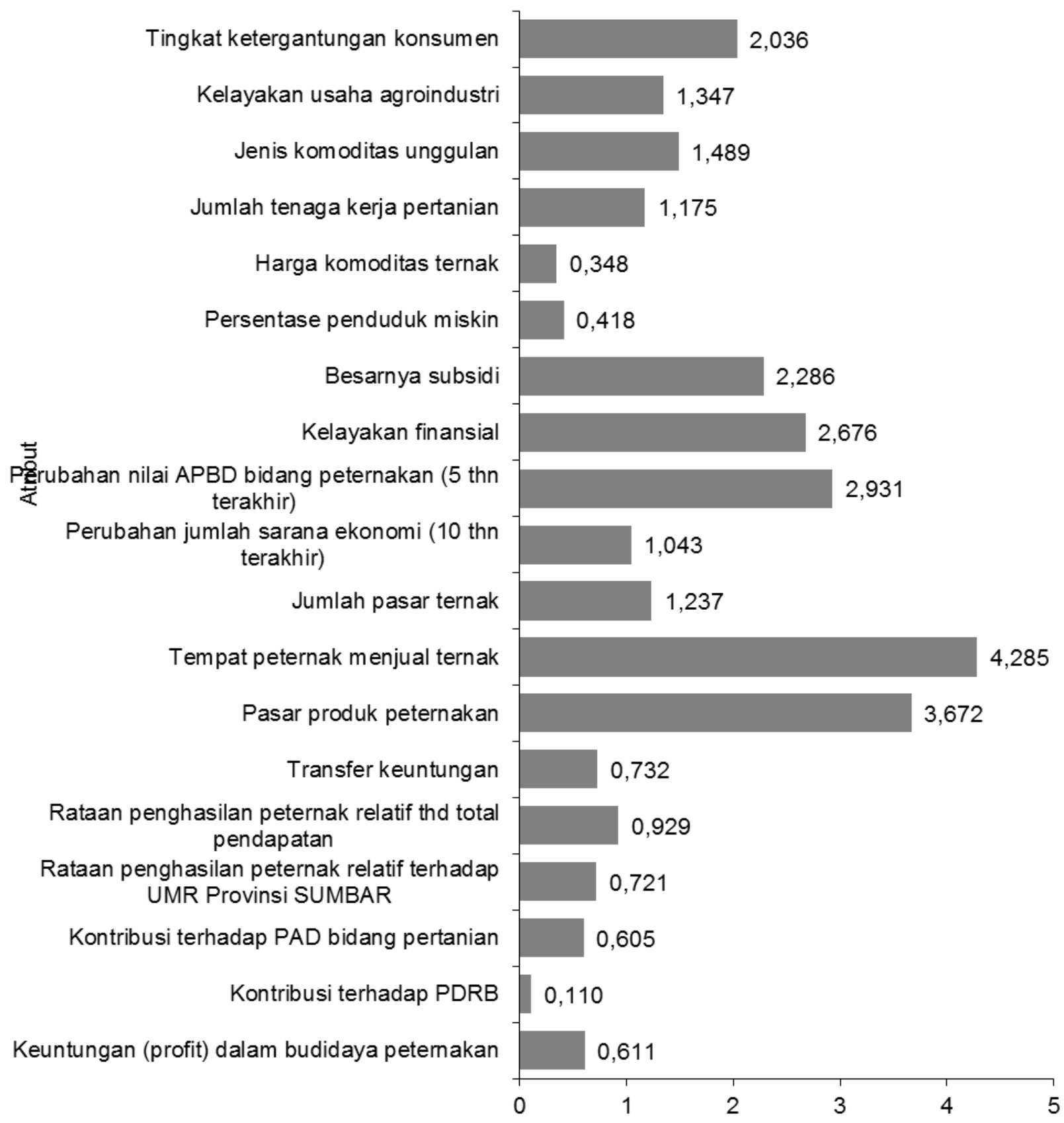

Root Mean Square Change \% in Ordination when Selected Attribute Removed (on Status scale 0 to 100 )

Gambar 6. Peran masing-masing atribut aspek ekonomi yang dinyatakan dalam bentuk nilai root mean square (RMS) 


\section{Analisis Leverage Dimensi Sosial Budaya}

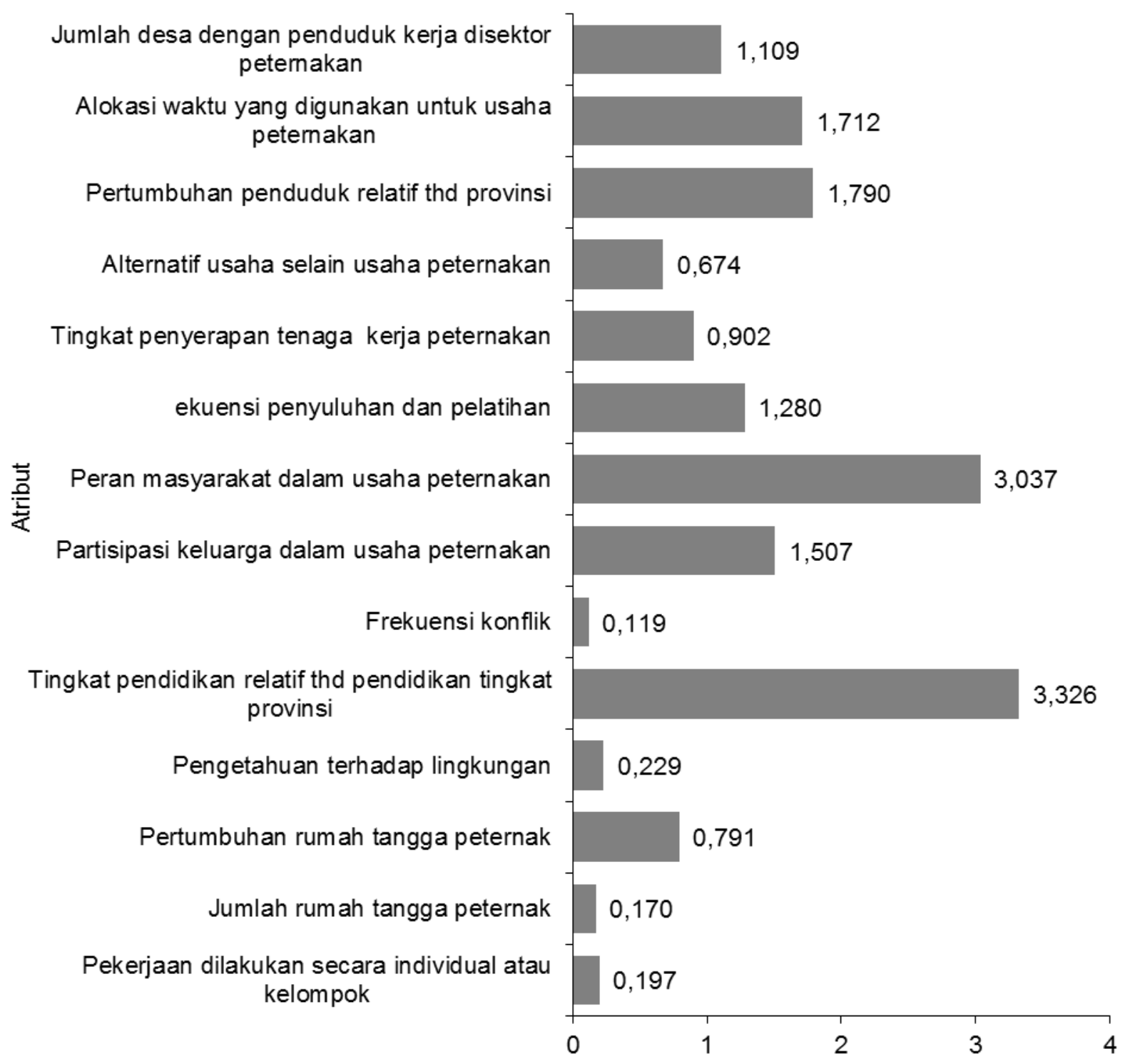

Root Mean Square Change \% in Ordination when Selected Attribute Removed (on Status scale 0 to 100 )

Gambar 7. Peran masing-masing atribut aspek sosial budaya yang dinyatakan dalam bentuk nilai root mean square (RMS) 


\section{Analisis Leverage Dimensi Teknologi dan Infrastruktur}

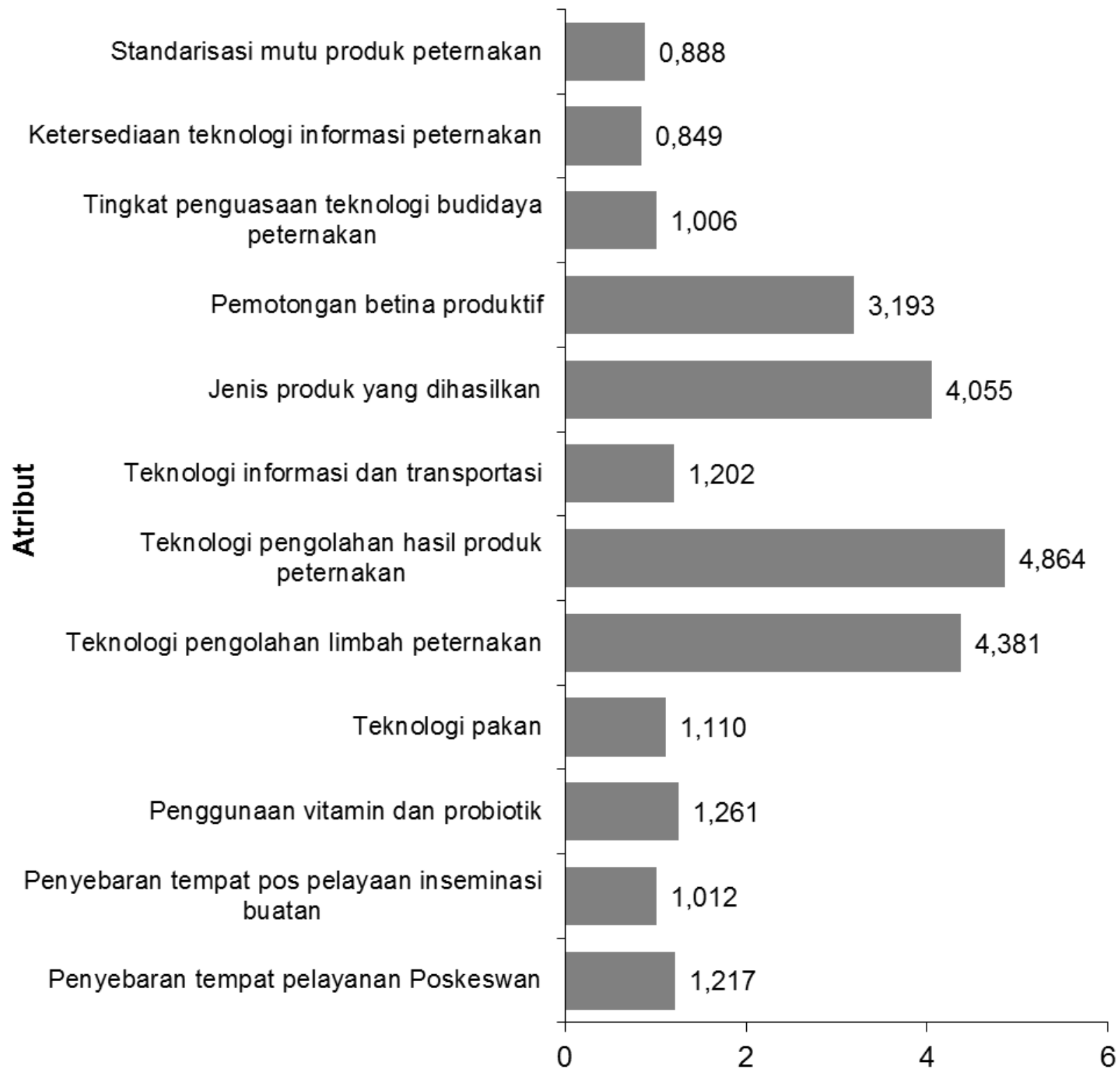

\section{Root Mean Square Change \% in Ordination when Selected Attribute Removed (on Status Scale 0 to 100)}

Gambar 8. Peran masing-masing atribut aspek teknologi dan infrastruktur yang dinyatakan dalam bentuk nilai root mean square (RMS) 


\section{Analisis Leverage Dimensi Hukum dan Kelembagaan}

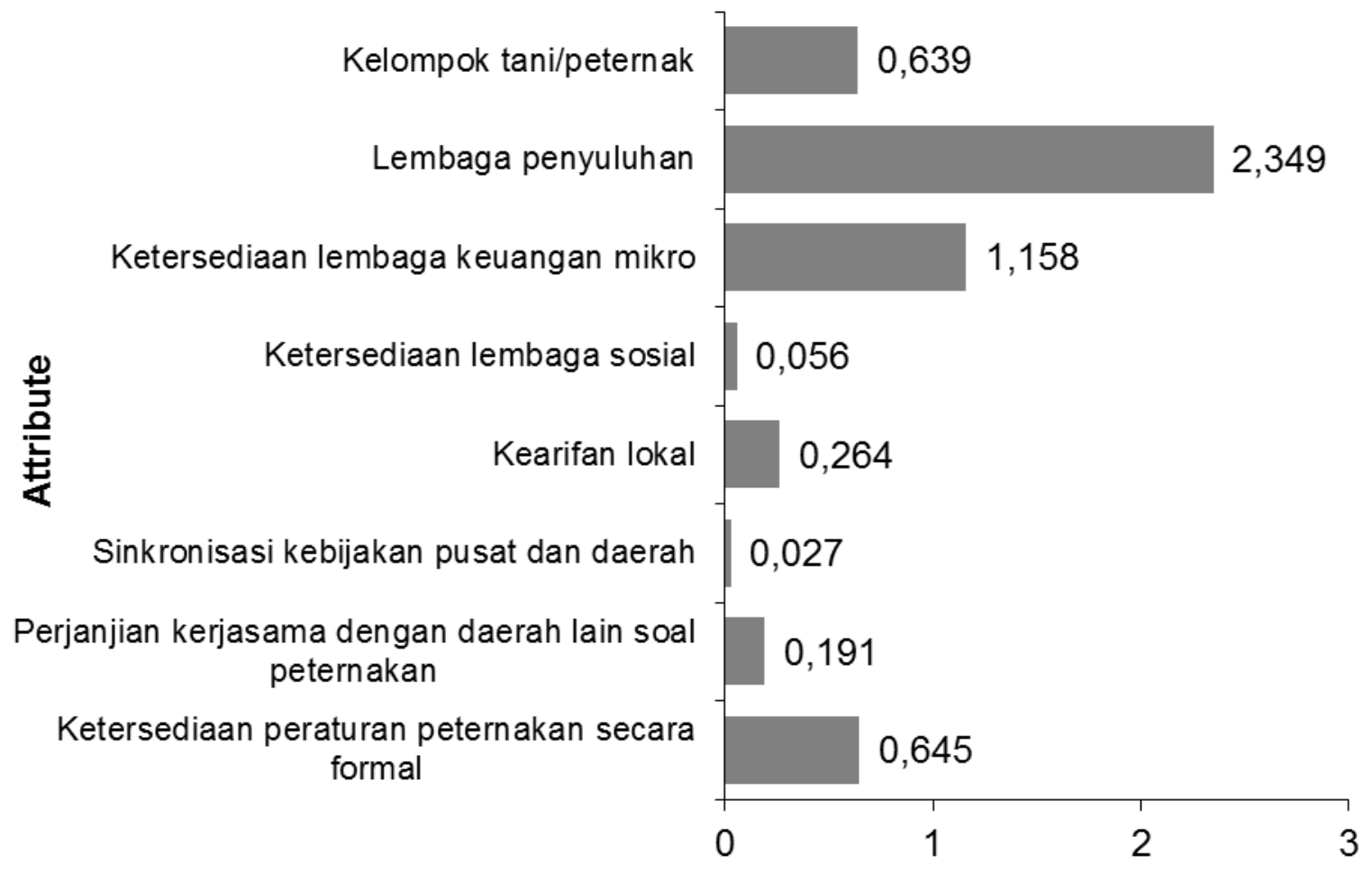

Root Mean Square Change \% in Ordination when Selected Attribute Removed (on Status scale 0 to 100)

Gambar 9. Peran masing-masing atribut aspek hukum dan kelembagaan yang dinyatakan dalam bentuk nilai root mean square (RMS)

Dengan demikian ketujuh faktor tersebut perlu dikelola dengan baik dan dibuat berbagai keadaan (state) yang mungkin terjadi di masa yang akan datang agar terwujud pengembangan kawasan berkelanjutan berbasis peternakan sapi potong terpadu di Kabupaten Lima Puluh Kota untuk mendukung pelaksanaan otonomi daerah.

Ketersediaan industri pengolahan hasil ternak, seperti: industri pengolahan daging sapi, industri pengolahan kulit, dan industri pupuk organik akan membutuhkan bahan baku ternak sapi potong yang cukup banyak, selain itu juga akan membutuhkan dan menyerap tenaga kerja yang cukup banyak di kawasan ini, membutuhkan ketersediaan rumah potong hewan yang memadai serta industri pakan ternak. Keberadaan industri hasil ternak ini juga akan mempengaruhi pasar produk hasil peternakan dan berdampak banyak (multiplier effects) terhadap perkembangan kawasan dan yang pada akhirnya akan meningkatkan Produk Domestik Regional Bruto (PDRB). Oleh sebab itu, ketersediaan industri pengolahan hasil ternak sangat membantu kawasan ini dalam rangka memajukan pertumbuhan kawasan dan meningkatkan PDRB daerah ini. Keberadaan industri pengolahan hasil ternak juga akan meningkatkan agribisnis komoditas unggulan lokalita, yang saling mendukung dan menguatkan termasuk industri kecil, pengolahan hasil, jasa pemasaran dan agrowisata 
dengan mengoptimalkan manfaat sumberdaya alam, secara efisien dan ekonomis, sehingga tidak ada limbah yang terbuang atau yang yang tidak dimanfaatkan untuk kesejahteraan masyarakat (usaha pertanian terpadu tanpa limbah).

Peternak dalam memberikan pakan pada umumnya sudah menanam rumput unggul di sekitar tempat tinggal dan memanfaatkan rumput alam yang banyak tumbuh di padang penggembalaan, kebun, hutan, serta memanfaatkan limbah pertanian dan limbah agroindustri pertanian yang cukup tersedia di wilayah ini. Dalam rangka menjamin ketersediaan pakan dan kecukupan gizi ternak, pembangunan industri pakan sangat dibutuhkan di daerah ini, apalagi ketersediaan produk pertanian (jagung) dan limbah pertanian (jerami padi, daun jagung, daun ketela pohon, dan daun kacang tanah) serta limbah industri pertanian (dedak padi, ampas tahu, ampas kecap, dan tongkol jagung) yang bisa dimanfaatkan untuk pakan ternak cukup banyak tersedia. Dengan adanya industri pakan ternak di wilayah ini, selain untuk memenuhi kebutuhan pakan ternak di daerah sendiri, selebihnya bisa dipasarkan ke be- berapa daerah, dan selain itu dapat menyerap tenaga kerja setempat serta memberikan multiplier effects terhadap wilayah ini, sehingga industri pakan dapat memberikan sumbangan pendapatan kepada masyarakat maupun daerah.

Dalam rangka membangun kawasan berbasis peternakan sapi potong terpadu yang maju, kehadiran koperasi sangat dibutuhkan untuk memudahkan masyarakat mencari suntikan dana/modal, menampung produk agroindustri peternakan dan memasarkannya, serta lebih mempermudah dalam pelayanan pembiayaan kegiatan ekonomi mikro masyarakat setempat. Koperasi yang terbentuk sebaiknya merupakan upaya kesadaran dan partisipasi dari masyarakat dalam menjalankan program pengembangan untuk kepentingannya sendiri. Pada pola ini masyarakatlah yang memiliki inisiatif dan berperan penuh pada kegiatankegiatan mereka, sehingga keberhasilannya sangat ditentukan dari rasa tanggungjawab dari masyarakat itu sendiri. Langkah awal dari pembentukan koperasi ini harus ada pendampingan, pengorganisasian, dan pemberdayaan masyarakat (Warner, 2002 dan Moe, 2004).

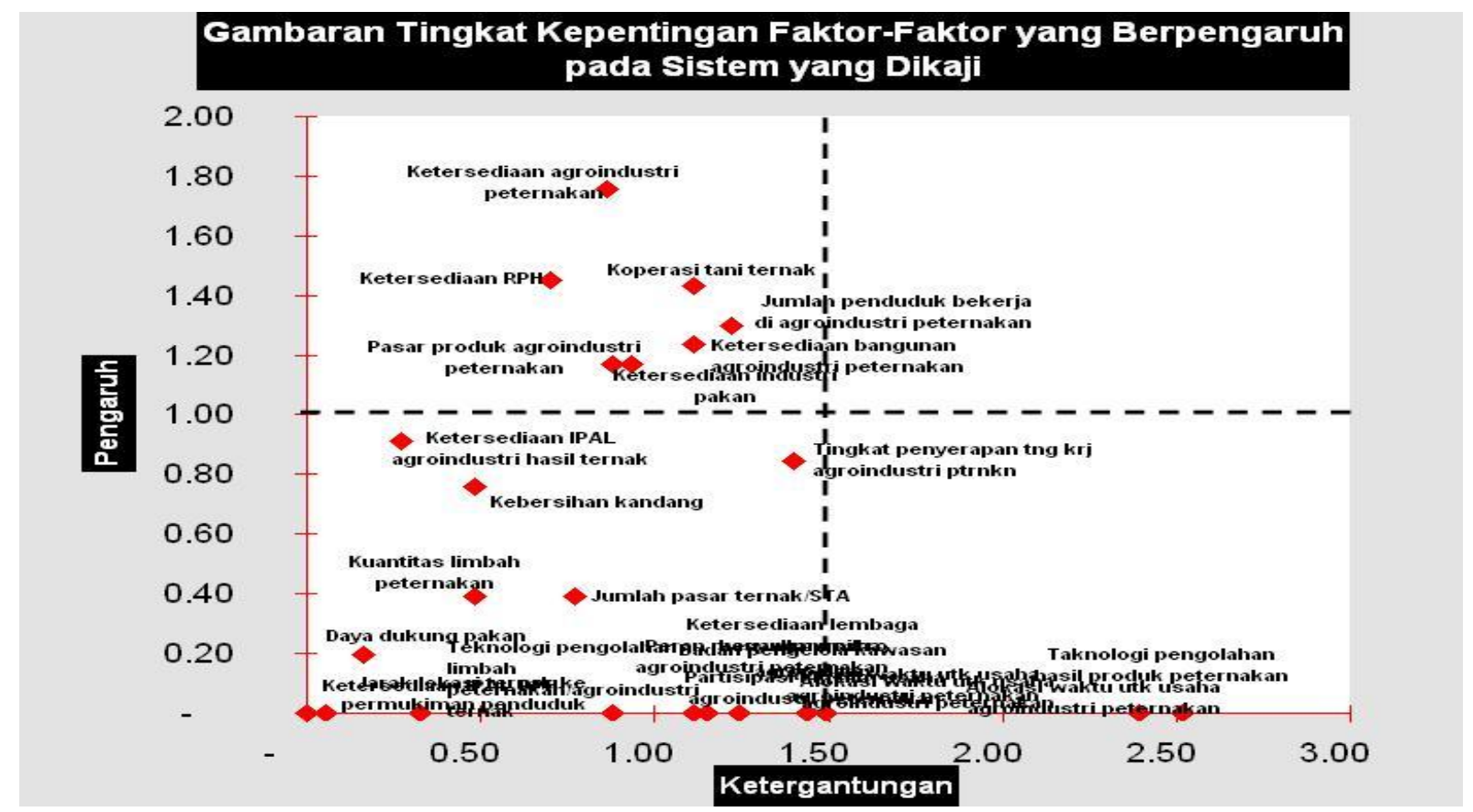

Gambar 7. Hasil analisis tingkat kepentingan faktor-faktor yang berpengaruh pada sistem yang dikaji 


\section{KESIMPULAN}

Berdasarkan kondisi eksisting lokasi penelitian berbasis peternakan di Kabupaten Lima Puluh Kota, dimensi ekologi, infrastruktur-teknologi, serta hukum dan kelembagaan kurang berkelanjutan, sedangkan dimensi ekonomi dan sosial budaya cukup berkelanjutan. Untuk meningkatkan status keberlanjutan kawasan di wilayah basis peternakan di Kabupaten Lima Puluh Kota adalah skenario progesif-optimistik dengan melakukan perbaikan secara menyeluruh terhadap semua atribut yang sensitif, minimal 7 atribut faktor kunci yang dihasilkan dalam analisis prospektif, sehingga semua dimensi menjadi berkelanjutan untuk pengembangan kawasan berbasis peternakan sapi potong terpadu.

\section{DAFTAR PUSTAKA}

Barlas, Y. 1996. Multiple test for validation of system dynamics type of simulation models. European Journal of Operational Research 42 (1): 59-87.

[BPS] Badan Pusat Statistik. 2011. Kabupaten Lima Puluh Kota Dalam Angka: Kerjasama Bappeda dan BPS Kabupaten Lima Puluh Kota. Payakumbuh.

Dubrovsky, V. 2004. Toward System Principles: General system theory and the alternative approach. J. System Research. Vol 21 (2): 109-123.
Evans, P. 2006. Government action, social capital and development: Reviewing the evidance of synergy. World Development 24 (6): 1119-1132.

Gao, F., M. Li and Y. Nakamori. 2003. Critical systems thinking as a way to manage knowladge. System Dynamics Review. 20(1): 3-19.

Kavanagh, P. 2001. Rapid Appraisal of Fisheries (Rapfish) Project. Rapfish Software Description (for Microsoft Exel). University of British Columbia, Fishries Centre. Vancouver.

Moe, T.M. 2004. The news economics of organizations. American Journal of Political Science. 28 (4):739-777.

Suyitman. 2010. Model pengembangan kawasan berkelanjutan berbasis peternakan sapi potong terpadu di Kabupaten Situbondo. Disertasi. Sekolah Pascasarjana IPB. Bogor.

Suyitman, Surjono Hadi Sutjahjo, Catur Herison, dan Muladno. 2009. Status keberlanjutan wilayah berbasis peternakan di Kabupaten Situbondo untuk pengembangan kawasan agropolitan. Jurnal Agroekonomi (JAE), Vol. 27 (2): 165-191.

Warner, M. 2002. Social capital construction and the role of the local state. Rural Sociology 64 (3): 373-393. 
Lampiran 1. Atribut-atribut yang dikaji dalam dimensi keberlanjutan wilayah berbasis peternakan sapi potong terpadu di Kabupaten Lima Puluh Kota

\begin{tabular}{|c|c|c|c|c|}
\hline Dimensi dan Atribut & Skor & Baik & Buruk & Keterangan \\
\hline \multicolumn{5}{|l|}{ Dimensi Ekologi } \\
\hline $\begin{array}{l}\text { Pemanfaatan limbah } \\
\text { peternakan untuk pupuk } \\
\text { organik. }\end{array}$ & & 3 & 0 & $\begin{array}{l}\text { (0) tidak dimanfaatkan; (1) sebagian kecil } \\
\text { dimanfaatkan; (2) sebagian besar } \\
\text { dimanfaatkan; (3) seluruhnya dimanfaatkan. }\end{array}$ \\
\hline $\begin{array}{l}\text { Pemanfaatan limbah } \\
\text { pertanian untuk pakan } \\
\text { ternak. }\end{array}$ & & 3 & 0 & $\begin{array}{l}\text { limbah pertanian: jerami padi, jerami } \\
\text { jagung, jerami kacang tanah, dan pucuk } \\
\text { tebu. (0) tidak dimanfaatkan; (1) sebagian } \\
\text { kecil dimanfaatkan; (2) sebagian besar } \\
\text { dimanfaatkan; (3) seluruhnya } \\
\text { dimanfaatkan. }\end{array}$ \\
\hline $\begin{array}{l}\text { Sistem pemeliharaan ternak } \\
\text { sapi potong. }\end{array}$ & & 3 & 0 & $\begin{array}{l}\text { Sistem pemeliharaan ternak tradisional } \\
\text { adalah ternak dipelihara dalam kandang dan } \\
\text { hanya diberi pakan rumput saja. } \\
\text { (0) }>50 \% \text { tradisional; (1) } 25-50 \% \text {; } \\
\text { (2) } 10-<25 \% \text {; (3) }<10 \% \text { tradisional. }\end{array}$ \\
\hline Lahan (kesuburan tanah). & & 2 & 0 & $\begin{array}{l}\text { Kesuburan tanah berdasarkan sifat kimia } \\
\text { tanah (Staf Pusat Penelitian Tanah } 1983 \text { ) } \\
\text { (0) tanah tidak subur: } \% \mathrm{~N}<0,20 \% \text { dan } \mathrm{pH} \\
<6,5 ;(1) \text { tanah kesuburan sedang: } \% \mathrm{~N} \text { : } \\
0,21-0,50 \% \text { dan pH: } 6,6-7,0 ;(2) \text { tanah } \\
\text { subur: \%N: >0,51\% dan pH: } 7,1-7,5 .\end{array}$ \\
\hline $\begin{array}{l}\text { Tingkat pemanfaatan } \\
\text { lahan untuk pertanian dan } \\
\text { peternakan. }\end{array}$ & & 2 & 0 & $\begin{array}{l}\text { (0) melebihi kapasitas; } \\
\text { (1) sedang; } \\
\text { (2) rendah. }\end{array}$ \\
\hline Agroklimat. & & 3 & 0 & $\begin{array}{l}\text { Mengacu pada type iklim di Indonesia } \\
\text { berdasarkan klasifikasi Schmidt \& Ferguson: } \\
\text { (0) agoklimat kering; (1) agroklimat } \\
\text { sedang; (3) agroklimat basah. }\end{array}$ \\
\hline Daya dukung pakan. & & 3 & 0 & $\begin{array}{l}\text { Mengacu pada Dinas Peternakan: } \\
\text { (0) sangat kritis; (1) kritis; (2) rawan; } \\
\text { (3) aman. }\end{array}$ \\
\hline $\begin{array}{l}\text { Ketersediaan IPAL } \\
\text { agroindustri hasil ternak. }\end{array}$ & & 3 & 0 & $\begin{array}{l}\text { (0) tidak ada; (1) ada tetapi sederhana (2) ada } \\
\text { dan kondisinya baik; (3) ada kondisinya } \\
\text { sangat baik }\end{array}$ \\
\hline Kebersihan kandang & & 1 & 0 & (0) kotor; (1) bersih \\
\hline $\begin{array}{l}\text { Ketersediaan Rumah } \\
\text { Potong Hewan (RPH). }\end{array}$ & & 2 & 0 & $\begin{array}{l}\text { Mengacu pada Dirjen Peternakan: } \\
\text { (0) type C; (1) type B; (2) type A. }\end{array}$ \\
\hline $\begin{array}{l}\text { Ketersediaan instalasi } \\
\text { pengelolaan limbah RPH. }\end{array}$ & & 3 & 0 & $\begin{array}{l}\text { (0) tidak ada; (1) ada tetapi sederhana; } \\
\text { (2) ada dan kondisinya baik; } \\
\text { (3) ada kondisinya sangat baik. }\end{array}$ \\
\hline Jenis pakan ternak. & & 2 & 0 & $\begin{array}{l}\text { (0) seadanya/hijauan alami; } \\
\text { (1) hijauan + limbah pertanian/agroindustri; } \\
\text { (2) hijauan + limbah pertanian/agroindustri } \\
\text { + konsentrat. }\end{array}$ \\
\hline Ketersediaan lahan untuk & & 3 & 0 & (0) tidak ada; (1) ada tetapi sedikit; \\
\hline
\end{tabular}




\begin{tabular}{|c|c|c|c|}
\hline $\begin{array}{l}\text { pakan ternak (rumput raja } \\
\text { dan rumput gajah). }\end{array}$ & & & (2) ada dan cukup; (3) Ada dan cukup luas. \\
\hline $\begin{array}{l}\text { Kuantitas limbah } \\
\text { peternakan. }\end{array}$ & 2 & 0 & (0) ada banyak; (1) sedikit; (2) tidak ada. \\
\hline $\begin{array}{l}\text { Jarak lokasi usaha } \\
\text { peternakan dengan } \\
\text { permukiman penduduk. }\end{array}$ & 2 & 0 & $\begin{array}{l}\text { (0) di lokasi permukiman; (1) dekat: } 50-100 \\
\text { m dari permukiman; (2) jauh: }>100 \mathrm{~m} \text { dari } \\
\text { permukiman. }\end{array}$ \\
\hline Kejadian kekeringan. & 2 & 0 & $\begin{array}{l}\text { (0) sering; (1) kadang-kadang; (2) tidak } \\
\text { pernah terjadi. }\end{array}$ \\
\hline Frekuensi kejadian banjir. & 2 & 0 & $\begin{array}{l}\text { (0) sering; (1) kadang-kadang; 2) tidak } \\
\text { pernah terjadi. }\end{array}$ \\
\hline Curah hujan. & 2 & 0 & (0) rendah; (1) sedang; (2) tinggi. \\
\hline $\begin{array}{l}\text { Kondisi prasarana jalan } \\
\text { usahatani. }\end{array}$ & 3 & 0 & $\begin{array}{l}\text { (0) Sangat jelek, (1) jelek, (2) agak baik } \\
\text { (3) baik. }\end{array}$ \\
\hline $\begin{array}{l}\text { Kondisi prasarana jalan } \\
\text { desa. }\end{array}$ & 3 & 0 & $\begin{array}{l}\text { (0) sangat jelek, (1) jelek, (2) agak baik } \\
\text { (3) baik. }\end{array}$ \\
\hline \multicolumn{4}{|l|}{ Dimensi Ekonomi } \\
\hline $\begin{array}{l}\text { Keuntungan (profit) dalam } \\
\text { budidaya peternakan sapi } \\
\text { potong. }\end{array}$ & 4 & 0 & $\begin{array}{l}\text { mengacu pada analisis usaha: Revenue Cost } \\
\text { Ratio }(\mathrm{R} / \mathrm{C}) \text { : } \\
(0) \text { rugi besar }(\mathrm{R} / \mathrm{C}<0,75) ;(1) \text { rugi sedikit } \\
(\mathrm{R} / \mathrm{C}: 0,75-1,0) ;(2) \text { kembali modal } \\
(\mathrm{R} / \mathrm{C}: 1,0) ;(3) \text { menguntungkan }(\mathrm{R} / \mathrm{C}: 1,0- \\
1,25) ; \quad(4) \text { sangat menguntungkan } \\
(\mathrm{R} / \mathrm{C}:>1,25) \text {. }\end{array}$ \\
\hline $\begin{array}{l}\text { Kontribusi terhadap } \\
\text { PDRB. }\end{array}$ & 2 & 0 & $\begin{array}{l}\text { (0) rendah: }<10 \% \text {; (1) sedang: } 10-20 \% \text {; } \\
\text { (2) tinggi: }>20 \% \text {. }\end{array}$ \\
\hline $\begin{array}{l}\text { Kontribusi terhadap } \\
\text { Pendapatan Asli Daerah } \\
\text { (PAD) untuk bidang } \\
\text { pertanian. }\end{array}$ & 2 & 0 & $\begin{array}{l}\text { (0) rendah: }<30 \% \text {; (1) sedang: } 30-50 \% \text {; } \\
\text { (2) tinggi: }>50 \% \text {. }\end{array}$ \\
\hline $\begin{array}{l}\text { Rataan penghasilan } \\
\text { peternak relatif terhadap } \\
\text { UMR Provinsi Sumbar. }\end{array}$ & 2 & 0 & $\begin{array}{l}\text { (0) di bawah; (1) sama; (2)) lebih tinggi } \\
\text { dari upah minimum regional (UMR). }\end{array}$ \\
\hline $\begin{array}{l}\text { Rataan penghasilan } \\
\text { peternak relatif terhadap } \\
\text { total pendapatan. }\end{array}$ & 2 & 0 & $(0)<30 \%$; (1) $30-70 \%$; (2)> $70 \%$ UMR \\
\hline Transfer keuntungan. & 2 & 0 & $\begin{array}{l}\text { (0) lebih banyak di penduduk luar daerah; } \\
\text { (1) seimbang antara lokal dan luar daerah; } \\
\text { (2) terutama berada di penduduk lokal. }\end{array}$ \\
\hline $\begin{array}{l}\text { Pasar produk agroindustri } \\
\text { peternakan. }\end{array}$ & 2 & 0 & $\begin{array}{l}\text { (0) pasar lokal; (1) pasar nasional; } \\
\text { (2) pasar internasional. }\end{array}$ \\
\hline $\begin{array}{l}\text { Ketersediaan pasar } \\
\text { ternak/sub terminal } \\
\text { agribisnis. }\end{array}$ & 2 & 0 & $\begin{array}{l}\text { (0) tidak ada; (1) ada pada desa tertentu; } \\
\text { (2) tersedia pada setiap desa. }\end{array}$ \\
\hline $\begin{array}{l}\text { Tempat peternak menjual } \\
\text { ternaknya. }\end{array}$ & 2 & 0 & $\begin{array}{l}\text { (0) lewat perantara; (1) pasar ternak; } \\
\text { (2) pengusaha industri pemotongan ternak } \\
\text { sapi potong. }\end{array}$ \\
\hline $\begin{array}{l}\text { Ketersediaan industri } \\
\text { pakan. }\end{array}$ & 2 & 0 & $\begin{array}{l}\text { (0) tidak ada; (1) ada pada desa tertentu; } \\
\text { (2) tersedia pada setiap desa. }\end{array}$ \\
\hline
\end{tabular}




\begin{tabular}{|c|c|c|c|}
\hline $\begin{array}{l}\text { Perubahan nilai APBD } \\
\text { bidang peternakan ( } 5 \\
\text { tahun terakhir). }\end{array}$ & 2 & 0 & (0) berkurang; (1) tetap; (2) bertambah. \\
\hline $\begin{array}{l}\text { Kelayakan finansial usaha } \\
\text { ternak sapi potong. }\end{array}$ & 2 & 0 & $\begin{array}{l}\text { Kelayakan finansial diukur berdasarkan } \\
\text { Revenue Cost Ratio }(\mathrm{R} / \mathrm{C}) \text { : } \\
\text { (0) tidak layak }(\mathrm{R} / \mathrm{C} ;<1) ;(1) \text { break event } \\
\text { point }(\mathrm{R} / \mathrm{C}=1) ; \quad \text { (2) layak }(\mathrm{R} / \mathrm{C}>1) .\end{array}$ \\
\hline Besarnya subsidi. & 4 & 0 & $\begin{array}{l}\text { (0) keharusan mutlak; (1) sangat tergantung; } \\
\text { (2) besar; (3) sedikit; (4) tidak ada. }\end{array}$ \\
\hline $\begin{array}{l}\text { Persentase penduduk } \\
\text { miskin. }\end{array}$ & 3 & 0 & $\begin{array}{l}\text { Penduduk miskin adalah penduduk yang } \\
\text { berpenghasilan di bawah UMR: } \\
\text { (0) sangat tinggi; (1) tinggi; (2) sedang; } \\
\text { (3) rendah. }\end{array}$ \\
\hline Harga komoditas ternak. & 3 & 0 & $\begin{array}{l}\text { (0) sangat tinggi; (1) tinggi; (2) sedang; } \\
\text { (3) rendah. }\end{array}$ \\
\hline $\begin{array}{l}\text { Jumlah tenaga kerja } \\
\text { pertanian. }\end{array}$ & 3 & 0 & $\begin{array}{l}\text { Tenaga kerja pertanian adalah orang yang } \\
\text { bekerja di bidang pertanian tanaman } \\
\text { pangan, perkebunan, dan peternakan } \\
\text { (0) sedikit; (1) sedang; (2) tinggi; (3) } \\
\text { sangat tinggi. }\end{array}$ \\
\hline Jenis komoditas unggulan. & 2 & 0 & $\begin{array}{l}\text { Komoditas unggulan adalah memiliki } \\
\text { prospek pasar, menguntungkan secara } \\
\text { ekonomi, potensinya besar, komoditas } \\
\text { dominan, dan digemari masyarakat } \\
\text { (0) hanya satu; (1) lebih dari satu; } \\
\text { (2) banyak. }\end{array}$ \\
\hline $\begin{array}{l}\text { Kelayakan usaha } \\
\text { agroindustri. }\end{array}$ & 1 & 0 & (0) tidak layak; (1) layak. \\
\hline $\begin{array}{l}\text { Tingkat ketergantungan } \\
\text { konsumen. }\end{array}$ & 2 & 0 & (0) rendah; (1) sedang; (2) tinggi. \\
\hline \multicolumn{4}{|l|}{ Dimensi Sosial Budaya } \\
\hline $\begin{array}{l}\text { Pekerjaan dilakukan } \\
\text { secara individual atau } \\
\text { kelompok. }\end{array}$ & 2 & 0 & $\begin{array}{l}\text { (0) pekerjaan secara individual; } \\
\text { (1) kerjasama satu keluarga; } \\
\text { (2) kerjasama kelompok. }\end{array}$ \\
\hline $\begin{array}{l}\text { Jumlah rumah tangga } \\
\text { peternakan. }\end{array}$ & 2 & 0 & $\begin{array}{l}(0)<1 / 3 ;(1) 1 / 3-2 / 3 ;(2)>2 / 3 \text { dari total } \\
\text { jumlah rumah tangga rencana kawasan. }\end{array}$ \\
\hline $\begin{array}{l}\text { Pertumbuhan rumah } \\
\text { tangga peternakan per } \\
\text { tahun (2006-2011) }\end{array}$ & 3 & 0 & $\begin{array}{l}(0)<10 \% ;(1) 10-20 \% ; \quad \text { (2) } 20-30 \% ; \\
(3)>30 \% .\end{array}$ \\
\hline $\begin{array}{l}\text { Pengetahuan terhadap } \\
\text { lingkungan. }\end{array}$ & 2 & 0 & $\begin{array}{l}\text { (0) sangat minim }<1 / 3 ;(1) \text { cukup: } 1 / 3- \\
2 / 3 ;(2) \text { banyak/luas: }>2 / 3 \text {. }\end{array}$ \\
\hline $\begin{array}{l}\text { Tingkat penyerapan } \\
\text { renaga kerja agroindustri } \\
\text { peternakan. }\end{array}$ & 2 & 0 & (0) tidak ada; (1) sedikit; 2) banyak. \\
\hline $\begin{array}{l}\text { Frekuensi konflik yang } \\
\text { berkaitan dengan } \\
\text { peternakan }\end{array}$ & 2 & 0 & (0) banyak; (1) sedikit; (2) tidak ada. \\
\hline $\begin{array}{l}\text { Partisipasi keluarga dalam } \\
\text { usaha agribisnis }\end{array}$ & 3 & 0 & $\begin{array}{l}\text { (0) tidak ada; (1) } 1 \text { - } 2 \text { anggota keluarga; } \\
\text { (2) 3-4 anggota keluarga; (3) }>5 \text { anggota }\end{array}$ \\
\hline
\end{tabular}




\begin{tabular}{|c|c|c|c|}
\hline peternakan. & & & keluarga. \\
\hline $\begin{array}{l}\text { Peran masyarakat dalam } \\
\text { usaha peternakan. }\end{array}$ & 2 & 0 & (0) tidak ada; (1) sedikit; (2) banyak. \\
\hline $\begin{array}{l}\text { Frekuensi penyuluhan dan } \\
\text { pelatihan. }\end{array}$ & 3 & 0 & $\begin{array}{l}\text { (0) tidak pernah ada; (1) sekali dalam } \\
\text { setahun; (2) dua kali dalam setahun; } \\
\text { (3) minimal tiga kali dalam setahun. }\end{array}$ \\
\hline $\begin{array}{l}\text { Tingkat penyerapan } \\
\text { tenaga kerja pertanian. }\end{array}$ & 3 & 0 & (0) rendah; (1) sedang; (3) tinggi. \\
\hline $\begin{array}{l}\text { Alternatif usaha selain } \\
\text { usaha agribisnis } \\
\text { peternakan. }\end{array}$ & 2 & 0 & (0) banyak; (1) sedikit; (2) tidak ada. \\
\hline $\begin{array}{l}\text { Jumlah penduduk yang } \\
\text { bekerja di bidang } \\
\text { agroindustri peternakan. }\end{array}$ & 2 & 0 & (0) tidak ada; (1) sedikit; (2) banyak. \\
\hline $\begin{array}{l}\text { Alokasi waktu yang } \\
\text { digunakan untuk usaha } \\
\text { agribisnis peternakan. }\end{array}$ & 3 & 0 & $\begin{array}{l}\text { (0) hanya hobby; (1) paruh waktu; } \\
\text { (2) musiman; (3) penuh waktu. }\end{array}$ \\
\hline $\begin{array}{l}\text { Jumlah desa dengan } \\
\text { penduduk bekerja di } \\
\text { sektor peternakan. }\end{array}$ & 2 & 0 & $\begin{array}{l}\text { (0) tidak ada; (1) desa tertentu saja; } \\
\text { (2) semua desa. }\end{array}$ \\
\hline \multicolumn{4}{|l|}{$\begin{array}{l}\text { Dimensi Teknologi dan } \\
\text { Infrastruktur }\end{array}$} \\
\hline $\begin{array}{l}\text { Penyebaran tempat } \\
\text { Poskeswan. }\end{array}$ & 3 & 0 & $\begin{array}{l}\text { (0) tidak dilakukan; (1) terpusat; (2) agak } \\
\text { terpusat; (3) tersebar. }\end{array}$ \\
\hline $\begin{array}{l}\text { Penyebaran pos } \\
\text { pelayanan inseminasi } \\
\text { buatan (IB). }\end{array}$ & 3 & 0 & $\begin{array}{l}\text { (0) tidak dilakukan; (1) terpusat; (2) agak } \\
\text { terpusat; (3) tersebar. }\end{array}$ \\
\hline $\begin{array}{l}\text { Penggunaan vitamin dan } \\
\text { probiotik untuk memacu } \\
\text { pertumbuhan ternak. }\end{array}$ & 2 & 0 & $\begin{array}{l}\text { (0) tidak pernah; (1) kadang-kadang; } \\
\text { (2) rutin. }\end{array}$ \\
\hline Teknologi pakan. & 2 & 0 & (0) tradisional; (1) sederhana; (2) modern. \\
\hline $\begin{array}{l}\text { Teknologi pengolahan } \\
\text { limbah peternakan/ } \\
\text { agroindustri peternakan }\end{array}$ & 2 & 0 & (0) tidak ada; (1) sederhana; (2) modern. \\
\hline $\begin{array}{l}\text { Teknologi pengolahan } \\
\text { hasil produk peternakan. }\end{array}$ & 2 & 0 & (0) tidak ada; (1) sederhana; (2) modern. \\
\hline $\begin{array}{l}\text { Teknologi informasi dan } \\
\text { transportasi. }\end{array}$ & 2 & 0 & (0) sangat minim; (1) cukup; (2) baik. \\
\hline $\begin{array}{l}\text { Ketersediaan sarana dan } \\
\text { prasarana agribisnis. }\end{array}$ & 2 & 0 & (0) sangat minim; (1) cukup; (2) lengkap. \\
\hline $\begin{array}{l}\text { Ketersediaan infrastruktur/ } \\
\text { sarana dan prasarana } \\
\text { umum. }\end{array}$ & 2 & 0 & (0) sangat minim; (1) cukup; (2) lengkap. \\
\hline $\begin{array}{l}\text { Tingkat penguasaan } \\
\text { teknologi budidaya } \\
\text { peternakan. }\end{array}$ & 2 & 0 & (0) rendah; (1) sedang; (2) tinggi. \\
\hline $\begin{array}{l}\text { Ketersediaan teknologi } \\
\text { informasi peternakan. }\end{array}$ & 2 & 0 & $\begin{array}{l}\text { (0) tidak tersedia; (1) tersedia tetapi tidak } \\
\text { optimal; (2) tersedia optimal. }\end{array}$ \\
\hline
\end{tabular}




\begin{tabular}{|c|c|c|c|}
\hline $\begin{array}{l}\text { Standarisasi mutu produk } \\
\text { peternakan. }\end{array}$ & 2 & 0 & $\begin{array}{l}\text { (0) belum diterapkan; (1) diterapkan pada } \\
\text { produk tertentu; (2) diterapkan untuk semua } \\
\text { produk. }\end{array}$ \\
\hline \multicolumn{4}{|l|}{$\begin{array}{l}\text { Dimensi Hukum dan } \\
\text { Kelembagaan }\end{array}$} \\
\hline $\begin{array}{l}\text { Pusat pelatihan dan } \\
\text { konsultasi milik petani. }\end{array}$ & 2 & 0 & $\begin{array}{l}\text { (0) belum ada; (1) ada tapi tidak berjalan } \\
\text { optimal; (2) ada dan berjalan optimal. }\end{array}$ \\
\hline $\begin{array}{l}\text { Perjanjian kerjasama } \\
\text { dengan daerah lain soal } \\
\text { peternakan. }\end{array}$ & 2 & 0 & $\begin{array}{l}\text { (0) belum ada; (1) ada tapi kurang berjalan } \\
\text { optimal; (2) ada dan berjalan optimal. }\end{array}$ \\
\hline $\begin{array}{l}\text { Sinkronisasi kebijakan } \\
\text { pusat dan daerah. }\end{array}$ & 2 & 0 & $\begin{array}{l}\text { (0) tidak sinkron; (1) kurang sinkron; } \\
\text { (2) sinkron. }\end{array}$ \\
\hline Kelompok tani ternak. & 2 & 0 & $\begin{array}{l}\text { (0) tidak ada; (1) ada tetapi kurang berjalan; } \\
\text { (2) ada dan berjalan. }\end{array}$ \\
\hline $\begin{array}{l}\text { Ketersediaan lembaga } \\
\text { sosial. }\end{array}$ & 2 & 0 & $\begin{array}{l}\text { (0) tidak ada; (1) ada tetapi kurang berjalan; } \\
\text { (2) ada dan berjalan. }\end{array}$ \\
\hline $\begin{array}{l}\text { Lembaga keuangan mikro } \\
\text { (bank/kredit). }\end{array}$ & 2 & 0 & $\begin{array}{l}\text { (0) tidak ada; (1) ada tetapi kurang berjalan; } \\
\text { (2) ada dan berjalan. }\end{array}$ \\
\hline $\begin{array}{l}\text { Lembaga penyuluhan } \\
\text { pertanian/BPP. }\end{array}$ & 2 & 0 & $\begin{array}{l}\text { (0) tidak ada; (1) ada tetapi kurang berjalan; } \\
\text { (2) ada dan berjalan. }\end{array}$ \\
\hline Badan pengelola kawasan. & 2 & 0 & $\begin{array}{l}\text { (0) tidak ada; (1) ada tetapi tidak berjalan; } \\
\text { (2) ada dan berjalan. }\end{array}$ \\
\hline
\end{tabular}

